\title{
Communication
}

[Comunicação]

\section{Inhibition of the growth of major mastitis-causing pathogens by non-aureus Staphylococcus isolates using the cross-streaking method}

\author{
[Comunicação: Inibição do crescimento dos principais patógenos \\ causadores de mastite por isolados de estafilococos \\ não aureus pelo método cross-streaking] \\ J.A. Ferronatto ${ }^{1,2}$, F.N. Souza $a^{2,3}$, A.M.M.P. Della Libera ${ }^{2}$, S. De Vliegher ${ }^{3}$, \\ A. De Visscher ${ }^{3}$, S. Piepers ${ }^{3}$, M.G. Blagitz ${ }^{2,4}$, M.B. Heinemann ${ }^{2}$ \\ ${ }^{1}$ Universidade do Oeste de Santa Catarina - Xanxerê, SC \\ ${ }^{2}$ Faculdade de Medicina Veterinária e Zootecnia - Universidade \\ de São Paulo - São Paulo, SP \\ ${ }^{3}$ Ghent University - Merelbeke, Belgium \\ ${ }^{4}$ Universidade Federal da Fronteira Sul - Realeza, PR
}

Mastitis is an inflammation of the mammary gland. This disease is typically caused by bacteria and has a significant economic impact on the global dairy industry. Escherichia coli, Staphylococcus aureus, Streptococcus agalactiae, Streptococcus dysgalactiae, and Streptococcus uberis are considered to be the main etiological agents of bovine mastitis (Taponen et al., 2017; Rainard et al., 2018). The prevention and control of mastitis is vital to the entire milk production chain, since this disease requires the highest use of antimicrobials in dairy herds. Excessive antimicrobial use has been shown to favor the emergence and selection of antimicrobial resistant bacteria (Stevens et al., 2018), reinforcing the urgency for alternatives in the prevention, control and treatment of mastitis.

Previous studies have demonstrated that a Staphylococcus chromogenes isolate from a heifer's teat apex inhibits the growth of important mastitis agents in vitro including $S$. aureus, $S$. dysgalactiae, $S$. uberis, and $S$. agalactiae (Vliegher et al., 2004; Braem et al., 2014). Furthermore, the isolation of non-aureus staphylococci (NAS) from the teat apex of dairy heifers prior to parturition has been shown to be related to protection against intramammary infections (IMIs) by major pathogens (Piepers et

Recebido em 6 de setembro de 2018

Aceito em 26 de março de 2019

E-mail: jose_augustoferronatto@usp.br al., 2011). Thus, it is suggested that NAS species may compete with other bacterial genera (Vliegher et al., 2004). In the last years, one of the most important bets is bacteriocins produced by NAS, which play an important role in the establishment and safeguarding of an ecological niche. With this in mind, a promising future option to treat mastitis is the use of bacteriocins, which present no risk of antibiotic residues in milk and would decrease the selection for antimicrobial resistance among mastitis-causing pathogens (Braem et al., 2014). In this study we used the cross-streaking method to evaluate the growth inhibition of major mastitis pathogens by bovine associated NAS isolates that were isolated from different ecological niches (milk, environment, and teat apex).

A total of 38 NAS isolates from different ecological niches were used to evaluate the potential growth inhibition of $S$. aureus, $S$. agalactiae, and S. uberis isolated from cows with subclinical mastitis and E. coli isolated from a cow with clinical mastitis. Among the NAS isolates, 15 were identified as Staphylococcus chromogenes (five of which were isolated from the teat apex, five from transient IMIs and five from persistent IMIs), 10 isolates were identified as Staphylococcus haemolyticus (five isolates from the teat apex and five from transient IMIs) 
and 13 isolates were identified as Staphylococcus fleurettii (five isolates from transient IMIs and eight from the dairy cows' environment). All NAS isolates were obtained from the Faculty of Veterinary Medicine, Ghent University, Belgium and were previously identified using biochemical and molecular tests. The study was approved by the Committee on Ethics of Animal Use (CEUA) at the Faculty of Veterinary Medicine and Animal Science of the University of São Paulo, number of the process - 8609270815. In vitro growth inhibition by NAS isolates was determined using the cross-streaking method, as previously described by Vliegher et al. (2004). Briefly, suspensions of each NAS isolate (MacFarland 0.5 standard) were plated using sterile and disposable handles on a $5 \mathrm{~mm}$ wide central strip on a petri dish containing defibrinated sheep blood agar $(5 \%)$. The plates were incubated at $37^{\circ} \mathrm{C}$ for $24 \mathrm{~h}$ under aerobic conditions. The agar was detached from the bottom of the petri dish with the aid of sterile disposable spatulas and placed on top of the lid, such that the NAS isolates were in direct contact with the lid of the petri dish, thus allowing the reverse side of the agar to be exposed. Next, suspensions of the mastitis pathogens (MacFarland 0.5 standard diluted to $10^{-3}$ ) were plated in the reverse side of the agar with the use of a sterile swab. After incubation for $24 \mathrm{~h}$ at $37^{\circ} \mathrm{C}$ under aerobic conditions, petri dishes were examined and measured $(\mathrm{mm})$ to determine whether there was partial inhibition $(\mathrm{P})$, total inhibition $(\mathrm{T})$ or no growth inhibition $(\mathrm{N})$. If present, all growth inhibition zones were determined and averaged on the left and the right sides along the axis across the plate, perpendicularly on the center streak zone. The total growth inhibition zone was regarded when no colony was observed, the partial growth inhibition zone was considered when smaller and/or less colonies was observed, and the zone of no growth inhibition were determined by the same size and numbers of colonies as on positive control plate. The results of this study are summarized in Table 1.

Here, it was observed that a $S$. chromogenes isolate with persistent IMI origin showed total inhibition against $S$. aureus, being the only isolate that showed total inhibition in our study, together with an extended partial inhibition zone. Although both partial and total inhibition of major mastitis pathogens by NAS were regarded here, it was hypothesized that the width of the inhibition zone and the type of inhibition (partial or total) are closely related to the concentrations of inhibitory substances produced by each NAS isolate that diffuse through the agar, such as bacteriocins. Altogether, it suggests that the $S$. chromogens isolate from a persistent IMI described above produced higher amounts of inhibitory substances than other studied NAS isolated here. Furthermore, it was observed that another isolate of $S$. chromogenes with the same origin and a $S$. chromogenes isolate from the teat apex presented partial inhibition against $S$. aureus.

Lastly, four isolates of $S$. fleurettii of environmental origin partially inhibited $S$. aureus. When analyzing $E$. coli, we could see that it was partially inhibited by an $S$. chromogenes isolate originating from transient IMI and also from an environmental isolate of $S$. fleurettii. Streptococcus uberis was partially inhibited by a $S$. chromogenes isolate originating from a persistent IMI, as well as a $S$. haemolyticus isolate from the teat apex. In addition, $S$. uberis was partially inhibited by isolates of $S$. fleurettii, one from an environmental origin and one from a transient IMI. Finally, S. agalactiae was partially inhibited by three isolates of $S$. chromogenes from the teat apex, one isolate of $S$. haemolyticus from the teat apex, and seven isolates of $S$. fleurettii (one from a transient IMI and six of environmental origin). In all, we had nineteen NAS isolates $(50 \%)$ from different origins among the 38 tested that demonstrated at least partial inhibition against at least one major mastitis-causing pathogen. The NAS isolates tested here that did not show any zone of growth inhibition of major mastitiscausing pathogens are not listed in Table 1 . We emphasize that the cross-streaking method is easy to perform and interpret, and allows for the selection of isolates capable of inhibiting the growth of mastitis-causing pathogens. This method should be followed up with an evaluation of the mechanism of inhibition in vitro, such as the possible production of bacteriocins. 
Table 1. In vitro inhibition of growth of major mastitis-causing pathogens by staphylococci non-aureus of different origins (apex teat, persistent and transient intramammary infections and environmental isolates) with a total of 19 isolates that demonstrated an inhibitory effect as determined by the cross-streaking method

\begin{tabular}{|c|c|c|c|c|c|}
\hline \multirow{2}{*}{$\begin{array}{l}\text { NAS species } \\
\text { (identification number) } \\
\text { Escherichia coli }\end{array}$} & \multirow{2}{*}{ Ecological niche } & \multicolumn{4}{|c|}{ Inhibition zone } \\
\hline & & $\mathrm{C}$ & $\mathrm{P}(\mathrm{mm})$ & $\mathrm{T}(\mathrm{mm})$ & $\mathrm{N}(\mathrm{mm})$ \\
\hline S. chromogenes (6) & Transient IMIs & $\mathrm{P}$ & 3.5 & 0 & 39 \\
\hline S. fleurettii (34) & Environment & $\mathrm{P}$ & 3.5 & 0 & 39 \\
\hline \multicolumn{6}{|l|}{ Streptococcus uberis } \\
\hline S. chromogenes (14) & Persistent IMI & $\mathrm{P}$ & 3.5 & 0 & 39 \\
\hline S. haemolyticus (19) & Teat apex & $\mathrm{P}$ & 3.0 & 0 & 39.5 \\
\hline S. fleurettii (27) & Transient IMI & $\mathrm{P}$ & 3.0 & 0 & 39.5 \\
\hline S. fleurettii (38) & Environment & $\mathrm{P}$ & 2.0 & 0 & 40.5 \\
\hline \multicolumn{6}{|l|}{ Streptococcus agalactiae } \\
\hline S. chromogenes (2) & Teat apex & $\mathrm{P}$ & 2.0 & 0 & 40.5 \\
\hline S. chromogenes (3) & Teat apex & $\mathrm{P}$ & 3.5 & 0 & 39 \\
\hline S. chromogenes $(5)$ & Teat apex & $\mathrm{P}$ & 3.0 & 0 & 39.5 \\
\hline S. haemolyticus (19) & Teat apex & $\mathrm{P}$ & 3.0 & 0 & 39.5 \\
\hline S. fleurettii (30) & Transient IMI & $\mathrm{P}$ & 3.0 & 0 & 39.5 \\
\hline S. fleurettii (31) & Environment & $\mathrm{P}$ & 4.0 & 0 & 38.5 \\
\hline S. fleurettii (32) & Environment & $\mathrm{P}$ & 3.0 & 0 & 39.5 \\
\hline S. fleurettii (33) & Environment & $\mathrm{P}$ & 3.5 & 0 & 39 \\
\hline S. fleurettii (35) & Environment & $\mathrm{P}$ & 2.5 & 0 & 40 \\
\hline S. fleurettii (37) & Environment & $\mathrm{P}$ & 3.0 & 0 & 39.5 \\
\hline S. fleurettii (38) & Environment & $\mathrm{P}$ & 3.0 & 0 & 39.5 \\
\hline \multicolumn{6}{|l|}{ Staphylococcus aureus } \\
\hline S. chromogenes (1) & Teat apex & $\mathrm{P}$ & 2.5 & 0 & 40 \\
\hline S. chromogenes (11) & Persistent IMI & $\mathrm{P}$ & 4.0 & 0 & 38.5 \\
\hline S. chromogenes (12) & Persistent IMI & $\mathrm{T}$ & 38.0 & 4.5 & 0 \\
\hline S. fleurettii (34) & Environment & $\mathrm{P}$ & 2.5 & 0 & 40 \\
\hline S. fleurettii (35) & Environment & $\mathrm{P}$ & 3.0 & 0 & 39.5 \\
\hline S. fleurettii (36) & Environment & $\mathrm{P}$ & 3.0 & 0 & 39.5 \\
\hline S. fleurettii (37) & Environment & $\mathrm{P}$ & 3.0 & 0 & 39.5 \\
\hline
\end{tabular}

${ }^{*} \mathrm{C}$ : central strip of NAS isolate, measuring $(5 \mathrm{~mm})$, t: total inhibition and p: partial inhibition; P: zone of partial growth inhibition of major pathogens causing mastitis; T: zone of total growth inhibition of major pathogens causing mastitis; N: zone with no growth inhibition of the major pathogens causing mastitis. NAS: non-aureus staphylococci; S. chromogenes: Staphylococcus chromogenes; S. fleurettii: Staphylococcus fleurettii; S. haemolyticus: Staphylococcus haemolyticus; IMI: intramammary infection.

Our results are in agreement with current literature (Woodward et al., 1987; Vliegher et al., 2004; Braem et al., 2014) that suggest that some NAS isolates, particularly S. chromogenes, could confer protection against major mastitiscausing pathogens. Indeed, Vliegher et al. (2004) showed that $S$. chromogenes isolates from teat apices inhibited the in vitro growth of Grampositive bacteria, but had no effect on Gramnegative bacteria (e.g. E. coli).

A previous study has suggested that the growth inhibition observed within and adjacent to the cross-streak zone could be explained by the production of antagonistic substances (e.g. bacteriocins) that diffuse through the agar and inhibit bacterial growth at the backside of the agar (Vliegher et al., 2004). The authors hypothesized that the degree of inhibition of major mastitis-causing pathogens by $S$. chromogenes was not identical against all species because the inhibitory effect of bacteriocins is usually more intense against phylogenetically related bacterial species. These facts may explain why we observed some inhibitory effect against Gram-positive bacteria, although, only a modest effect was observed against $E$. coli. 
Similarly, Woodward et al. (1987) conducted an in vitro study showing that $25 \%$ of NAS that were isolated from the teat apex of heifers were able to inhibit the growth of $E$. coli and $S$. aureus. However, the degree of inhibition differed between Gram-positive and Gramnegative bacteria, with greater inhibition observed in Gram-positive bacteria, as found here.

As described above, NAS are capable of inhibiting the growth of primary mastitis-causing pathogens. Nascimento et al. (2005) have shown in an in vitro study that NAS isolated from bovine mastitis cases produce bacteriocins capable of inhibiting the growth of $S$. agalactiae, similar to our work using the cross-streaking method, suggesting that NAS can be used to inhibit the major pathogens causing mastitis. Braem et al. (2014) observed that some NAS isolated from bovine teat apex skin, when tested against major mastitis pathogens such as $S$. aureus and $S$. uberis, demonstrated considerable growth inhibition in an in vitro study. The same study was the first to identify a bacteriocin of $S$. chromogenes L217, referred to as nukacin L217. Bacteriocins are antimicrobial peptides synthesized by the ribosomes of Gram-positive bacteria and act primarily to inhibit bacterial growth of similar species (Nascimento et al., 2005; Carson et al., 2017). In another study, Carson et al. (2017) concluded that $21 \%$ of NAS isolated from bovine milk are capable of inhibiting $S$. aureus. Although bacteriocins produced by staphylococci show promise for antibacterial therapies, including reducing of antibiotic resistant strains of Staphylococcus, their use for treatment of mastitis is still limited (Braem et al., 2014).

In in vivo study by Vliegher et al. (2003), it was observed that prepartum teat apex colonization with $S$. chromogenes appeared to protect mammary quarters from having high somatic cell counts in the first few days of lactation. In previous in vivo studies, Matthews et al. (1990) and Poutrel and Lerondelle (1980) found that mammary quarters that had previous contact with $S$. chromogenes were less prone to become infected when subjected to $S$. aureus inoculation compared to mammary quarters that had no previous contact. Similarly, Piepers et al. (2011) conducted an epidemiological study showing that colonization of the heifer teat apex by NAS in the prepartum period conferred a protective effect against IMI by major causative agents of mastitis. Taken together, these results suggest that NAS may have a potential protective effect against other pathogens, such as $S$. aureus.

To the best of our knowledge, this study is the first that evaluates the potential inhibition of major mastitis pathogens by NAS isolated from different ecological niches (milk, environment and teat apex). Initially, we postulated that NAS strains isolated from the teat apex are more likely to produce antagonist substances against other bacteria due to evolutionary pressure and bacterial competition to colonize the teat apex. Conversely, we hypothesized that NAS isolated from the mammary gland environment (e.g. NAS isolated from persistent IMIs) are less likely to produce antagonist substances, as the pressure and selection may be mainly related to evading host immune defense mechanisms. Thus, we propose that the ecological niche influences the ability of the NAS to inhibit the growth of the major pathogen of mastitis. For example, we expected that NAS isolated from the teat apex is related to a greater chance of inhibiting mastitiscausing pathogens. However, this phenomenon was not observed in our research, therefore, more studies using larger numbers of isolates are needed.

Thus, here it was shown that some NAS isolates can inhibit the growth of major mastitis pathogens, especially against Gram-positive bacteria, however, the ecological niche did not determine this beneficial effect.

JAF thanks the National Council for Scientific Development and Technological Development CNPq (144516/2016-0) for his fellowship. FNS also thanks São Paulo Research Foundation FAPESP (2014/23189-4) for his fellowship. MBH (309146/2017-8) is indebted to Conselho Nacional de Desenvolvimento Científico e Tecnológico - CNPq for research fellowships. We thank São Paulo Research Foundation FAPESP (2015/10332-6) for the financial support and the Coordenação de Aperfeiçoamento de Pessoal de Nivel Superior Brasil (CAPES) - Finance Code 001.

Keywords: dairy cows, coagulase-negative staphylococci, intramammary infection 


\section{RESUMO}

O objetivo do presente estudo foi avaliar a capacidade de estafilococos não aureus (NAS) isolados de diferentes nichos ecológicos (leite, ambiente e ápice do teto), associados a vacas leiteiras, de inibir os principais agentes etiológicos da mastite bovina (Staphylococcus aureus, Streptococcus agalactiae, Streptococcus uberis e Escherichia coli). Neste estudo, 38 isolados NAS de diferentes nichos ecológicos foram avaliados quanto à capacidade de inibir o crescimento in vitro de importantes patógenos causadores de mastite pelo método cross-streaking. No total, 19 (50\%) isolados de NAS (oito isolados de $\mathrm{S}$. chromogenes, $10 \mathrm{de} \mathrm{S}$. fleurettii $e$ um de $\mathrm{S}$. haemolyticus) apresentaram inibição contra os principais patógenos causadores de mastite. No entanto, a inibição dos patógenos causadores da mastite bovina por isolados de NAS foi maior contra bactérias Gram-positivas. Além disso, o presente estudo não sugeriu que os nichos ecológicos influenciam a capacidade do NAS de inibir os principais patógenos causadores da mastite bovina. Com base nesses resultados, concluiu-se que certos isolados de NAS apresentam potencial efeito protetor contra os principais patógenos da mastite, pelo menos in vitro.

Palavras-chave: bovinos de leite, estafilococos coagulase-negativos, infecção intramamária

\section{REFERENCES}

BRAEM, G.; STIJLEMANS, B.; VAN HAKEN, W.; DE VLIEGHER, S. et al. Antibacterial activities of coagulase-negative staphylococci from bovine teat apex skin and their inhibitory effect on mastitis-related pathogens. J. Appl. Microbiol., v.116, p.1084-1093, 2014.

CARSON, D.A.; BARKEMA, H.W.; NAUSHAD, S.; DE BUCK, J. Bacteriocins of non-aureus staphylococci isolated from bovine milk. Appl. Environ. Microbiol., v.83, p.1015-1017, 2017.

MATTHEWS, K.R.; HARMON, R.J.; SMITH, B.A. Protective effect of $S$. chromogenes infection against $S$. aureus infection in the lactating bovine mammary gland. J. Dairy Sci., v.73, p.3457-3462, 1990.

NASCIMENTO, J.S.; FAGUNDES, P.C.; BRITO, M.A.V.P.; SANTOS, K.R.N. et al. Production of bacteriocins by coagulase-negative staphylococci involved in bovine mastitis. Vet. Microbiol., v.106, p.61-71, 2005.

PIEPERS, S.; PEETERS, K.; OPSOMER, G.; BARKEMA, H.W. et al. Pathogen group specific risk factors at herd, heifer and quarter levels for intramammary infections in early lactating dairy heifers. Prev. Vet. Med., v.99, p.91-101, 2011.

POUTREL, B.; LERONDELLE, C. Protective effect in the lactating bovine mammary gland induced by coagulase-negative staphylococci against experimental Staphylococcus aureus infections. Ann. Rech. Vet., v.11, p. 327-332. 1980.
RAINARD, P.; FOUCRAS, G.; FITZGERALD, J.R.; WATTS, J.L. et al. Knowledge gaps and research priorities in Staphylococcus aureus mastitis control. Transbound. Emerg. Dis., v.65, Suppl.1, p.149-165, 2018.

STEVENS, M.; PIEPERS, S.; SUPRÉ, K.; DE VLIEGHER, S. Antimicrobial consumption on dairy herds and its association with antimicrobial inhibition zone diameters of non-aureus staphylococci and Staphylococcus aureus isolated from subclinical mastitis. J. Dairy Sci., v.101, p.3311-3322, 2018.

TAPONEN, S.; LISKI, E.; HEIKKILÄ, A.M.; PYÖRÄLÄ, S. Factors associated with intramammary infection in dairy cows caused by coagulase-negative staphylococci, Staphylococcus aureus, Streptococcus uberis, Streptococcus dysgalactiae, Corynebacterium bovis, or Escherichia coli. J. Dairy Sci., v.100, p.493503, 2017.

VLIEGHER, S.; LAEVENS, H.; DEVRIESE, L.A.; OPSOMER, G. et al. Prepartum teat apex colonization with $S$. chromogenes in dairy heifers is associated with low somatic cell count in early lactation. Vet. Microbiol., v.92, p.245-252, 2003.

VLIEGHER, S.; OPSOMER, G.; VANROLLEGHEM, L.A.; DEVRIESE, L.A. et al. In vitro growth inhibition of major mastitis pathogens by Staphylococcus chromogenes originating from teat apices of dairy heifers. Vet. Microbiol., v.101, p.215221,2004

WOODWARD, W.D.; BESSER, T.E.; WARD, A.C.S.; CORBEIL, L.B. In vitro growth inhibition of mastitis pathogens by bovine teat skin normal flora. Can. J. Vet. Res., v.51, p.27-31, 1987. 